\title{
Pigmenting efficacy of astaxanthin fed to rainbow trout Oncorhynchus mykiss: Effect of dietary astaxanthin and lipid sources
}

\author{
Georges Choubert ${ }^{\mathrm{a}, *}$, Maria Manuela Mendes-Pinto ${ }^{\mathrm{b}}$, Rui Morais ${ }^{\mathrm{b}}$ \\ ${ }^{a}$ INRA, UMR 1067, Nutrition, Aquaculture et Génomique, Pôle d'Hydrobiologie, 64310 Saint-Pée-sur-Nivelle, France \\ ${ }^{\mathrm{b}}$ Escola Superior de Biotecnologia, Universidade Católica Portuguesa, Rua Dr. António Bernardino de Almeida, 4200-072 Porto, Portugal
}

Keywords: Astaxanthin; Haematococcus pluvialis; Fish oil; Olive oil; Pigmentation; Trout

\begin{abstract}
The aim of the present experiment was to investigate the effect of two different dietary types of oil (fish oil (FI) and olive oil (OL)) on the pigmenting efficacy of astaxanthin from the green micro-algae Haematococcus pluvialis (ALG) (total amount of carotenoid pigments $32 \mathrm{mg} \mathrm{kg}^{-1}$ on a dry weight basis of which astaxanthin accounted for 98.6\%) and from the synthetic astaxanthin (AST) in terms of astaxanthin serum concentration, induced muscle colour, and astaxanthin muscle retention in rainbow trout for 6 weeks. Diets with different oil sources were well accepted by fish. At the end of the experiment there were no significant differences between fish fed different diets in final mean weight, specific growth rate, or feed conversion ratio. Fish fed AST showed higher $(P<0.05)$ serum concentrations than those fed ALG. Moreover fish fed diets OL displayed higher $(P<0.05)$ serum astaxanthin levels than those fed diets FI. Fish muscle colour parameters reacted differently according to fish feed. Over 6 weeks of feeding $L^{*}$ compared to $L^{*}$ of initial sampling time showed a decrease more marked for trout fed ASTFI than ALGFI. Fish fed ASTOL and ALGOL displayed intermediary values. On the contrary the other colour parameters increased except hue $H\left({ }^{\circ}\right)_{a b}$ which did not show any change whatever diet was fed to the fish. Chroma $C^{*}, a^{*}$, and $b^{*}$ data obtained for fish fed AST were higher than those obtained for fish fed ALG. Muscle astaxanthin concentrations were lower $(P<0.05)$ for fish fed algae than for those fed synthetic astaxanthin. After 6 weeks of experiment muscle astaxanthin levels were not different $(P>0.05)$ for fish fed olive or fish oil. Muscle astaxanthin retention was higher $(P<0.05)$ for fish fed AST than for fish fed ALG.
\end{abstract}

\section{Introduction}

The colour of salmonids is an important criterion of quality. The typical red to pink muscle colour of salmonids is due to astaxanthin $\left(3,3^{\prime}\right.$-dihydroxy- $\beta, \beta$-carotene-

\footnotetext{
* Corresponding author. Tel.:+33559515951; fax:+33559545152. E-mail address: choubert@st-pee.inra.fr (G. Choubert).
}

4,4'-dione), a carotenoid from dietary origin that fish cannot synthesize. In the wild fish derive astaxanthin through their prey organisms while in intensive rearing system astaxanthin is added to the feed in the form of nature identical synthetic beadlets (Bjerkeng et al., 1999). However, more and more natural alternative sources are expected to be used as for example the green micro-algae Haematococcus pluvialis. This algae, when 
subjected to stress full culture conditions, produces astaxanthin as primary carotenoid up to $1-3 \%$ of dry weight (Lorenz and Cysewski, 2000).

Carotenoids are lipid-soluble compounds. Therefore the amount and type of lipid with which they are consumed may influence their absorption. Several studies involving different amounts of dietary lipid have produced conflicting results (see review by Torrissen et al., 1989). On the other hand information on the effect of different types of dietary lipid on carotenoid utilization is relatively sparse. Atlantic salmon fed diets containing menhaden oil had higher canthaxanthin in their muscle than salmon fed diets containing soybean oil (Hardy et al., 1987; Regost et al., 2004) or rapeseed oil (Regost et al., 2004). However, no difference in astaxanthin concentration was noted in the muscle of salmon when fish oil was replaced by rapeseed oil (Bell et al., 2001) or palm oil (Bell et al., 2002). On the other hand it has been shown that salmon fed high $n-3$ PUFA (polyunsaturated fatty acids) oil had higher muscle astaxanthin content than those fed herring oil (Bjerkeng et al., 1999).

The aim of the present experiment was to investigate the effect of different dietary oils on the pigmenting efficacy of astaxanthin in terms of astaxanthin serum concentration, induced muscle colour, and astaxanthin muscle retention by feeding olive oil replacing fish oil to rainbow trout for 6 weeks. Astaxanthin sources were green micro-algae $H$. pluvialis and synthetic astaxanthin.

\section{Materials and methods}

\section{Fish and feeding management}

The experiment took place at the INRA Experimental Station of Donzacq (Landes Department, South West of France). Two hundred and seventy six rainbow trout, Oncorhynchus mykiss, from the same parental stock were randomly divided in four groups in square tanks (300 1) set in parallel rows supplied with spring water (constant temperature $17 \pm 1{ }^{\circ} \mathrm{C} ; \mathrm{pH} 7.4 ; \mathrm{Cl}^{-} 22.5 \mathrm{mg}$ $\mathrm{l}^{-1} ; \mathrm{Ca}^{2+} 75 \mathrm{mg} \mathrm{l}^{-1}$; dissolved oxygen $8 \mathrm{mg} \mathrm{l}^{-1}$ ) at a rate of $1.41 \mathrm{~min}^{-1}$. Tanks received a natural photoperiod (October to November). Prior to introduction to the experimental diets and during the acclimatization period, fish were fed a commercial non-astaxanthin supplemented feed for 15 days (Trouw France, Fontaine-lesVervins, France). Then fish, reaching a mean weight of $185 \mathrm{~g}$, were fed the 4 experimental diets in triplicate $(23$ fish $\operatorname{tank}^{-1}$ ) for 6 weeks. Fish were hand fed twice a day $(08: 30 \mathrm{~h}, 16: 30 \mathrm{~h})$ an equal quantity of feed 7 days week ${ }^{-1}$ at a rate of $2.5 \%$ body weight day ${ }^{-1}$ (BWD) and complete feed ingestion was assessed visually. At each 2-week period an adjustment of the daily ration was made according to the fish growth.

\section{Experimental diets}

Four test diets with the same basal composition (Table 1) were supplemented with two different lipid sources, fish oil and olive oil, compositions of which are given in Table 2 and two different astaxanthin sources at

Table 1

Formulas, ingredients and chemical composition of the 4 experimental feeds (AST, ALG: diets containing synthetic astaxanthin or algae, respectively; FI, OL: diets containing fish oil or olive oil, respectively)

\begin{tabular}{|c|c|c|c|c|}
\hline Diet label & ASTFI & ASTOL & ALGFI & ALGOI \\
\hline \multicolumn{5}{|l|}{ Feed ingredients $\left(\mathrm{g} \mathrm{kg}^{-1}\right)$} \\
\hline Fish meal $^{\mathrm{a}}$ & 580 & 580 & 580 & 580 \\
\hline Gelatinised wheat starch ${ }^{\mathrm{b}}$ & 160 & 160 & 160 & 160 \\
\hline Crude wheat $\operatorname{starch}^{\mathrm{c}}$ & 130 & 130 & 130 & 130 \\
\hline Olive oil $^{\mathrm{d}}$ & - & 10 & - & 10 \\
\hline Fish oil ${ }^{\mathrm{e}}$ & 10 & - & 10 & - \\
\hline Vitamin $\operatorname{mix}^{\mathrm{f}}$ & 10 & 10 & 10 & 10 \\
\hline Mineral mix ${ }^{g}$ & 10 & 10 & 10 & 10 \\
\hline Sodium alginate ${ }^{\mathrm{h}}$ & 10 & 10 & 10 & 10 \\
\hline Astaxanthin ${ }^{\mathrm{i}}$ & + & + & & \\
\hline Algae & & & + & + \\
\hline \multicolumn{5}{|l|}{ Feed chemical composition ${ }^{\mathrm{j}}$} \\
\hline Dry matter DM (\%) & 95.38 & 94.42 & 94.91 & 94.58 \\
\hline Total lipids (\% DM) & 15.24 & 15.26 & 15.01 & 16.15 \\
\hline Astaxanthin (mg kg$\left.{ }^{-1} \mathrm{DM}\right)$ & 80.2 & 78.1 & 72.6 & 71.1 \\
\hline
\end{tabular}

${ }^{a}$ Norwegian herring meal, Norse LT94. Sopropêche, Boulogne-surmer, France.

b Amidex, Ogilvie Aquitaine, Bordeaux, France.

c Amidaine B, Ogilvie Aquitaine, Bordeaux, France.

d Olive oil extravirgin quality, Euroliva Cia Oleícola S.L., Plasencia, Spain.

${ }^{\mathrm{e}}$ Feedoil, Scandinavian fish oil. Sopropêche, Lorient, France.

${ }^{\mathrm{f}}$ INRA 762. Vitamin mix contained the following mixed with cellulose $\left(\mathrm{g} \mathrm{kg}^{-1} \mathrm{mix}\right)$ : vitamin A $\left(500,000 \mathrm{IU} \mathrm{g}^{-1}\right), 1.5$; vitamin D3 $\left(100,000 \mathrm{IU} \mathrm{g}^{-1}\right), 1.5$; vitamin E $\left(500 \mathrm{IU} \mathrm{g}^{-1}\right), 6$; vitamin $\mathrm{K}, 0.25$; thiamin, 0.75 ; riboflavin, 1.5 ; pyridoxine, 0.75 ; nicotinic acid, 8.75 ; vitamin C, 25; folic acid, 0.25 ; vitamin $B_{12}\left(1000 \mathrm{mg} \mathrm{kg}^{-1}\right), 2.5$; inositol, 50; biotin $\left(2 \mathrm{mg} \mathrm{kg}^{-1}\right), 6.25$; calcium pantothenate, 2.5; choline (50 $\left.\mathrm{mg} \mathrm{kg}^{-1}\right), 200$.

$\mathrm{g}$ INRA 763. Mineral mix contained the following ingredients $\left(\mathrm{g} \mathrm{kg}^{-1}\right.$ mix): calcium carbonate, 215 ; magnesium hydroxide, $124 ; \mathrm{KCl}, 90$; ferric citrate, 20; KI, $0.4 ; \mathrm{NaCl}, 40$; calcium hydrogen phosphate $\left(\mathrm{CaHPO}_{4}\right), 500$; copper sulfate, 3 ; zinc sulfate, 4 ; cobalt sulfate, 0.2 ; manganese sulfate, 3 .

h Alginate GF 150. Louis François Exploitation, Saint Maur, France.

${ }^{\text {i }}$ CAROPHYLL ${ }^{\circledR}$ pink, DSM (formerly F. Hoffman-La Roche), Basel, Switzerland.

${ }^{\mathrm{j}}$ Means of 2 independent determinations. 
Table 2

Fatty acid composition of dietary oils (\% by wt of total fatty acids) $)^{(1)}$

\begin{tabular}{|c|c|c|}
\hline Fatty acid & Fish oil & Olive oil \\
\hline $12: 0$ & 0.2 & 0 \\
\hline $14: 0$ & 15.4 & 0 \\
\hline $14: 1$ & 0.2 & 0 \\
\hline $15: 0$ & 0.7 & 0 \\
\hline $16: 0$ & 19.7 & 14.3 \\
\hline $16: 1$ & 9.4 & 1.3 \\
\hline $16: 2 n-7$ & 0.4 & 0 \\
\hline $16: 2 n-4$ & 1.0 & 0 \\
\hline $16: 4 n-1$ & 0.3 & 0 \\
\hline $17: 0$ & 0.2 & 0 \\
\hline $17: 1$ & 0.3 & 0 \\
\hline $18: 0$ & 1.3 & 0 \\
\hline $18: 1$ & 16.1 & 75.2 \\
\hline $18: 2 n-6$ & 1.8 & 4.5 \\
\hline $18: 3$ & 0.3 & 0 \\
\hline $18: 3 n-3$ & 1.1 & 0.6 \\
\hline $18: 4$ & 3.1 & 0 \\
\hline $20: 0$ & 0.1 & 3.4 \\
\hline $20: 1$ & 8.1 & 0.2 \\
\hline $20: 2$ & 0.1 & 0 \\
\hline $20: 4$ & 0.2 & 0 \\
\hline $20: 5$ & 4.7 & 0 \\
\hline $22: 1$ & 7.4 & 0 \\
\hline $22: 5$ & 0.2 & 0 \\
\hline $22: 6 n-3$ & 3.5 & 0 \\
\hline $\mathrm{SFA}^{(2)}$ & 37.6 & 17.7 \\
\hline MUFA $^{(3)}$ & 41.5 & 76.7 \\
\hline PUFA $n-6^{(4)}$ & 4.1 & 4.5 \\
\hline PUFA $n-3$ & 13.2 & 0.6 \\
\hline SFA/PUFA & 2.2 & 3.5 \\
\hline PUFA $n-3 / n-6$ & 3.2 & 0.1 \\
\hline
\end{tabular}

${ }^{(1)}$ Mean of duplicate samples; ${ }^{(2)}$ Saturated fatty acids; ${ }^{(3)}$ Monounsaturated fatty acids; ${ }^{(4)}$ Polyunsaturated fatty acids.

a level of $75 \mathrm{mg}$ astaxanthin $\mathrm{kg}^{-1}$ of feed. The two carotenoid sources used were algae $H$. pluvialis strain CCAP-34/7 (Culture Collection of Algae and Protozoa, Windermere, UK) cultivated under the same conditions as described by Mendes-Pinto et al. (2001), and commercial beadlets of $8 \%(\mathrm{w} / \mathrm{w})$ astaxanthin content (CAROPHYLL ${ }^{\circledR}$ Pink, DSM Nutritional product (formerly F. Hoffmann-La Roche), Basel, Switzerland). Algae were mechanically ground in a ball grinder (grinder Dangoumeau, Prolabo, Fontenay-sous-bois, France) for 5 min prior to diet incorporation and the cell wall disruption was assessed by optical microscopy (BioMed, Leitz, Westlar, Germany). Diets were pelleted using a steamless pelleting machine (M-Labor, Simon Heesen B.V., Boxtel, The Netherlands) through a $4.5 \mathrm{~mm}$ dye. Pellets were allowed to dry at $38{ }^{\circ} \mathrm{C}$ for $4 \mathrm{~h}$ (dryer Bulkit, Monclar, France) and were stored at $4{ }^{\circ} \mathrm{C}$ prior to use. Proximate composition of experimental diets is given in Table 1.

\section{Sampling and analytical methods}

Four fish per tank were sampled and sacrificed by a sharp blow on cervical vertebrae at regular intervals of 2 weeks $(0,2,4$, and 6 weeks). Fish blood was collected from the caudal artery with a $2 \mathrm{ml}$ non-heparinized disposable syringes fitted with $0.6 \times 25 \mathrm{~mm}$ disposable needles (Becton Dickinson France, Le Pont de Claix, France) and analysed for astaxanthin as described by Mendes-Pinto et al. (2004).

Muscle colour was assessed immediately postslaughter by using a chromameter (mod. CR200, Minolta Co. Ltd., Osaka, Japan) equipped with a $8 \mathrm{~mm}$ diameter aperture and calibrated on a white reference plate before use as described by Choubert et al. (1997). Measurements were processed at three locations along the fillet above the lateral line: close to the head; midway between the head and the tail; and close to the tail. All measurements were performed in the colorimetric space $L^{*} a^{*} b^{*}$ in accordance with the recommendations of the Commission Internationale de l'Éclairage (CIE, 1976). They were then transformed in the $L^{*} C^{*} H\left({ }^{\circ}\right)_{a b}$ colorimetric space according to Wyszecki and Stiles (1967). In this space the three dimensional characteristics of colour appearance are the lightness attribute $L^{*}$ and the two chromatic attributes hue $H\left(^{\circ}\right)_{a b}$ and chroma $C^{*}$.

Biochemical analyses of diets and muscles were dry matter (DM), total lipids (Folch et al., 1957) and astaxanthin concentrations (Choubert and Storebakken, 1989). For carotenoid extraction, micro-algal biomass was prior mechanically ground for 5 min (grinder Dangoumau, Prolabo, Fontenay-sous-Bois, France). Determination of total carotenoids content was made by UV-Visible spectrophotometry according to Mendes-Pinto et al. (2004). For diets containing algae, astaxanthin was analysed after lipid extraction (Folch et al., 1957) and quantified by spectrophotometry as described above. For diets

Table 3

Serum astaxanthin concentrations ${ }^{(1)(2)}$ of trout fed different astaxanthin and lipid sources calculated as ratio [total blood astaxanthin per unit body weight to cumulative astaxanthin intake per unit body weight]

\begin{tabular}{lllll}
\hline \multirow{2}{*}{$\begin{array}{l}\text { Sampling } \\
\text { time }\end{array}$} & \multicolumn{4}{l}{ Diet $^{(3)}$} \\
\cline { 2 - 5 } & ASTFI & ASTOL & ALGFI & \multicolumn{1}{c}{ ALGOL } \\
\hline 2 weeks & $12.1 \pm 3.7^{\mathrm{a}, \mathrm{b}}$ & $15.7 \pm 5.4^{\mathrm{a}}$ & $9.1 \pm 3.7^{\mathrm{a}, \mathrm{b}}$ & $6.9 \pm 2.0^{\mathrm{b}, \mathrm{c}}$ \\
4 weeks & $33.9 \pm 7.7^{\mathrm{b}}$ & $69.5 \pm 23.0^{\mathrm{a}}$ & $7.0 \pm 2.3^{\mathrm{c}}$ & $9.0 \pm 2.8^{\mathrm{c}}$ \\
6 weeks & $17.9 \pm 4.9^{\mathrm{b}}$ & $48.6 \pm 20.1^{\mathrm{a}}$ & $38.3 \pm 17.5^{\mathrm{a}}$ & $21.9 \pm 3.0^{\mathrm{b}}$
\end{tabular}

\footnotetext{
${ }^{(1)}$ Mean \pm S. D., $n=4$.

${ }^{(2)}$ Within a row means with different superscripts are significantly different, Tuckey's multiple comparisons test, $(P<0.05)$.

${ }^{(3)}$ AST, ALG: diets containing synthetic astaxanthin or algae, respectively; FI, OL: diets containing fish oil or olive oil, respectively.
} 
Table 4

Colour parameters of trout muscle during two, four, six weeks $\left(2 \mathrm{w}, 4 \mathrm{w}\right.$, and $6 \mathrm{w}$, respectively) sampling times ${ }^{(1)(2)}$

\begin{tabular}{|c|c|c|c|c|c|}
\hline \multirow{2}{*}{$\begin{array}{l}\text { Colour } \\
\text { parameters }\end{array}$} & \multirow{2}{*}{$\begin{array}{l}\text { Sampling } \\
\text { times }\end{array}$} & \multicolumn{4}{|l|}{$\operatorname{Diets}^{(3)}$} \\
\hline & & $\mathrm{ASTFI}^{(3)}$ & ASTOL & ALGFI & ALGOL \\
\hline \multirow[t]{4}{*}{$L^{*}$} & 0 & $41.32 \pm 1.76$ & $41.32 \pm 1.76$ & $41.32 \pm 1.76$ & $41.32 \pm 1.76$ \\
\hline & $2 w$ & $40.98 \pm 1.44^{\mathrm{b}}$ & $40.41 \pm 1.59^{\mathrm{b}}$ & $42.76 \pm 2.08^{\mathrm{a}}$ & $41.82 \pm 0.85^{\mathrm{a}, \mathrm{b}}$ \\
\hline & $4 \mathrm{w}$ & $39.61 \pm 1.15^{\mathrm{b}}$ & $38.48 \pm 1.94^{\mathrm{b}}$ & $41.65 \pm 1.34^{\mathrm{a}}$ & $40.00 \pm 2.36^{\mathrm{a}, \mathrm{b}}$ \\
\hline & $6 \mathrm{w}$ & $37.98 \pm 2.31^{\mathrm{c}}$ & $38.50 \pm 1.58^{\mathrm{b}, \mathrm{c}}$ & $41.33 \pm 2.36^{\mathrm{a}}$ & $40.16 \pm 1.55^{\mathrm{a}, \mathrm{b}}$ \\
\hline \multirow[t]{4}{*}{$C^{*}$} & 0 & $2.48 \pm 0.45$ & $2.48 \pm 0.45$ & $2.48 \pm 0.45$ & $2.48 \pm 0.45$ \\
\hline & $2 w$ & $6.85 \pm 2.28^{\mathrm{a}}$ & $7.01 \pm 2.55^{\mathrm{a}}$ & $2.94 \pm 1.82^{\mathrm{b}}$ & $3.82 \pm 1.35^{\mathrm{b}}$ \\
\hline & $4 \mathrm{w}$ & $9.40 \pm 3.04^{\mathrm{a}, \mathrm{b}}$ & $11.31 \pm 2.62^{\mathrm{a}}$ & $5.23 \pm 2.62^{\mathrm{c}}$ & $7.36 \pm 2.24^{\mathrm{b}, \mathrm{c}}$ \\
\hline & $6 \mathrm{w}$ & $13.17 \pm 3.46^{\mathrm{a}}$ & $12.79 \pm 1.87^{\mathrm{a}}$ & $7.13 \pm 2.73^{b}$ & $8.63 \pm 1.62^{\mathrm{b}}$ \\
\hline \multirow[t]{4}{*}{$H\left({ }^{\circ}\right)_{a b}$} & 0 & $154.89 \pm 91.76$ & $154.89 \pm 91.76$ & $154.89 \pm 91.76$ & $154.89 \pm 91.76$ \\
\hline & $2 \mathrm{w}$ & $56.32 \pm 7.21^{\mathrm{a}, \mathrm{b}}$ & $57.38 \pm 4.81^{\mathrm{a}, \mathrm{b}}$ & $73.52 \pm 30.88^{\mathrm{a}}$ & $54.54 \pm 11.22^{\mathrm{b}}$ \\
\hline & $4 \mathrm{w}$ & $59.28 \pm 7.85^{\mathrm{a}}$ & $58.04 \pm 2.69^{\mathrm{a}}$ & $57.71 \pm 8.08^{\mathrm{a}}$ & $56.15 \pm 5.84^{\mathrm{a}}$ \\
\hline & $6 \mathrm{w}$ & $56.54 \pm 3.09^{\mathrm{a}}$ & $58.63 \pm 2.88^{\mathrm{a}}$ & $55.77 \pm 4.89^{\mathrm{a}}$ & $57.55 \pm 3.06^{\mathrm{a}}$ \\
\hline \multirow[t]{4}{*}{$a^{*}$} & 0 & $0.94 \pm 0.46$ & $0.94 \pm 0.46$ & $0.94 \pm 0.46$ & $0.94 \pm 0.46$ \\
\hline & $2 w$ & $3.66 \pm 1.16^{\mathrm{a}}$ & $3.72 \pm 1.74^{\mathrm{a}}$ & $1.44 \pm 0.68^{\mathrm{b}}$ & $2.06 \pm 0.64^{\mathrm{b}}$ \\
\hline & $4 \mathrm{w}$ & $5.18 \pm 1.44^{\mathrm{a}, \mathrm{b}}$ & $6.05 \pm 1.73^{\mathrm{a}}$ & $2.61 \pm 1.16^{\mathrm{c}}$ & $3.99 \pm 1.19^{\mathrm{b}, \mathrm{c}}$ \\
\hline & $6 \mathrm{w}$ & $7.21 \pm 1.89^{\mathrm{a}}$ & $6.67 \pm 1.05^{\mathrm{a}}$ & $3.95 \pm 1.59^{\mathrm{b}}$ & $4.65 \pm 1.03^{\mathrm{b}}$ \\
\hline \multirow[t]{4}{*}{$b^{*}$} & 0 & $1.69 \pm 0.84$ & $1.69 \pm 0.84$ & $1.69 \pm 0.84$ & $1.69 \pm 0.84$ \\
\hline & $2 w$ & $5.75 \pm 2.04^{\mathrm{a}}$ & $5.91 \pm 2.24^{\mathrm{a}}$ & $2.40 \pm 1.85^{\mathrm{b}}$ & $3.13 \pm 1.33^{\mathrm{b}}$ \\
\hline & $4 \mathrm{w}$ & $7.73 \pm 2.98^{\mathrm{a}, \mathrm{b}}$ & $9.54 \pm 2.03^{\mathrm{a}}$ & $4.47 \pm 2.43^{\mathrm{c}}$ & $6.13 \pm 2.01^{b, c}$ \\
\hline & $6 \mathrm{w}$ & $10.99 \pm 2.96^{\mathrm{a}}$ & $10.89 \pm 1.67^{\mathrm{a}}$ & $5.88 \pm 2.29^{\mathrm{b}}$ & $7.25 \pm 1.33^{\mathrm{b}}$ \\
\hline
\end{tabular}

${ }^{(1)}$ Data are mean $\pm \mathrm{SD}, n=4$.

${ }^{(2)}$ Means on the same line not sharing the same letter are significantly different $(P<0.05)$.

${ }^{(3)}$ AST, ALG: diets containing synthetic astaxanthin or algae, respectively; FI, OL: diets containing fish oil or olive oil, respectively.

${ }^{(4)} L^{*}=$ lightness with $100=$ absolute white and $0=$ absolute black; $C^{*}=$ chroma calculated as $\left(a^{*}+b^{*}\right)^{1 / 2}($ Wyszecki and Stiles, 1967$) ; H\left({ }^{\circ}\right)_{a b}=$ Hue angle determined as $\arctan b^{*} / a^{*}$ (Wyszecki and Stiles, 1967); $a^{*}=$ "redness" coordinate; $b^{*}=$ "yellowness" coordinate.

containing synthetic astaxanthin the method of Schüep and Schierle (1995) was performed.

Fatty acid methyl esters were prepared by acidcatalyzed transmethylation of total lipids using boron trifluoride methanol according to Santha and Ackman (1990). The chromatograph (mod. 3400, Varian inc., Palo Alto, USA) was equipped with a DB Wax fused silica capillary column $(30 \mathrm{~m} \times 0.25 \mathrm{~mm}$ i.d., film thickness: $0.25 \mu \mathrm{m}$, J and W Scientific, Folsom, USA). Helium was used as carrier gas $\left(1.4 \mathrm{ml} \mathrm{min}^{-1}\right)$ and the thermal gradient was 100 to $180{ }^{\circ} \mathrm{C}$ at $8{ }^{\circ} \mathrm{C} \mathrm{min}{ }^{-1}, 180$ to $220^{\circ} \mathrm{C}$ at $4{ }^{\circ} \mathrm{C} \mathrm{min}{ }^{-1}$ and a constant temperature of $220{ }^{\circ} \mathrm{C}$ during $25 \mathrm{~min}$. Injector and flame ionisation detector temperatures were 260 and $250{ }^{\circ} \mathrm{C}$, respectively. Fatty acid methyl esters were identified and quantified by comparison with known standard mixtures (\# 189-19, Sigma-Aldrich Co, Saint Quentin Fallavier, France).

Serum astaxanthin concentrations were calculated as ratio [total blood astaxanthin per unit body weight to cumulative astaxanthin intake per unit body weight]. A mean whole trout blood volume of $3 \% \mathrm{BW}$ at a water temperature of $16^{\circ} \mathrm{C}$ was used for calculation according to Nikinmaa et al. (1981).
Trout muscle astaxanthin retention was calculated according to the following equation (Choubert and Luquet, 1982):

Muscle astaxanthin retention

$=\left[\right.$ final muscle astaxanthin concentration $\left(\mathrm{mg} \mathrm{kg}^{-1} \mathrm{DM}\right)$

$\times($ final muscle mean weight $(\mathrm{kg} \mathrm{DM}))$

-initial muscle astaxanthin concentration $\left(\mathrm{mg} \mathrm{kg}^{-1} \mathrm{DM}\right)$

$\times($ initial muscle mean weight $(\mathrm{kg} \mathrm{DM}))] /$

[feed consumed ( $\mathrm{kg} \mathrm{DM})$

$\times$ diet astaxanthin concentration $\left.\left(\mathrm{mg} \mathrm{kg}^{-1} \mathrm{DM}\right)\right] 100$.

Data were subjected to analysis of variance and Tuckey's multiple comparison test using SAS-GLM procedures (SAS, 1989). A significance level of 5\% was assumed.

\section{Results}

Fish oil (Table 2) contained $37.6 \%$ saturated fatty acids, mainly 14:0 (15.4\%) and 16:0 (19.7\%), 41\% monounsaturated fatty acids, mainly 18:1 (16.1\%) and $20: 1(8.1 \%)$, and $17.3 \%$ polyunsaturated fatty acids, mainly 18:3 $n-3$ (1.1\%), 18:2 n-6 (1.8\%), and 22:6n 


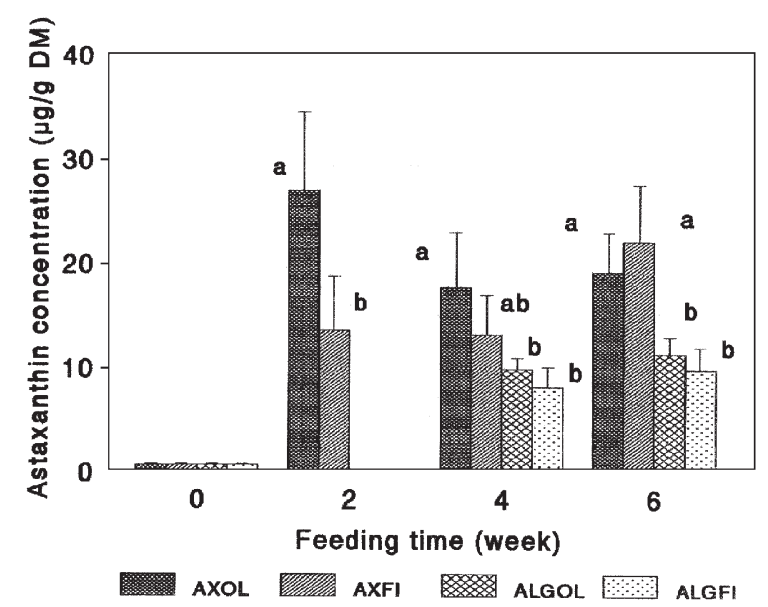

Fig. 1. Muscle astaxanthin concentrations of fish fed during 6 weeks diets containing synthetic astaxanthin (AST) or algae (ALG), respectively; and containing fish oil (FI) or olive (OL) oil, respectively.

$-3(3.5 \%)$. Olive oil contained $17.7 \%$ saturated fatty acids, mainly 16:0 (14.3\%) and 20:0 (3.4\%), 76.7\% monounsaturated fatty acids, mainly 18:1 (75.2\%), and 5.1\% polyunsaturated fatty acids, mainly 18:2 $n-6(4.5 \%)$.

The total amount of carotenoid pigments in microalgae $H$. pluvialis was $32 \mathrm{mg} \mathrm{kg}^{-1}$ on a dry weight basis of which astaxanthin accounted for $98.6 \%$.

Diets with different oil sources were well accepted by fish and no mortalities occurred. At the end of the experiment there were no significant $(P>0.05)$ differences between fish fed the different diets in final mean weight (overall mean, $345 \mathrm{~g}$ ), specific growth rate (overall mean, 0.96 ) and feed conversion ratio (overall mean, 1.66).

Serum astaxanthin concentrations of trout fed different astaxanthin and lipid sources are reported in Table 3. Fish fed AST showed higher $(P<0.05)$ astaxanthin serum concentrations than those fed ALG. Moreover fish fed diets containing OL displayed higher $(P<0.05)$ serum astaxanthin levels than those fed diets containing FI. Fish fed diet ASTOL showed highest levels of serum astaxanthin while fish fed ALGOL presented the lowest levels of serum astaxanthin except at the 6 week sampling time. A positive time effect was also only noted for astaxanthin serum concentration from fish fed algae.

Colour parameters of muscle of trout fed the different experimental diets are shown in Table 4. Over 6 weeks of feeding $L^{*}$ compared to $L^{*}$ of initial sampling time showed a decrease more marked for trout fed ASTFI than ALGFI. Fish fed ASTOL and ALGOL displayed intermediary values. On the contrary the other colour parameters increased except hue $H\left({ }^{\circ}\right)_{a b}$ which did not show any difference among dietary treatment groups. Chroma $C^{*}, a^{*}$, and $b^{*}$ data obtained for fish fed AST were higher than those obtained for fish fed ALG. Hues were similar among fish fed the different diets and $L^{*}$ showed lower values for fish fed AST compared to fish fed ALG.

Muscle astaxanthin concentrations are plotted on Fig. 1. Muscle astaxanthin concentrations were lower $(P<0.05)$ for fish fed algae than for those fed synthetic astaxanthin. After 6 weeks of experiment muscle astaxanthin levels were not different $(P>0.05)$ for fish fed olive or fish oil.

Astaxanthin retentions in the muscle of rainbow trout fed the different diets are given in Table 5. At the end of the first two weeks of experiment fish receiving ASTOL displayed a significant $(P<0.05)$ higher muscle astaxanthin retention than fish fed ASTFI. Muscle astaxanthin retentions calculated after 4 weeks or 6 weeks were lower than those calculated after 2 weeks. Muscle astaxanthin retentions were higher $(P<0.05)$ for fish fed synthetic astaxanthin than for those fed algae. There were no (pigment source $\times$ oil source) or (sampling time (pigment source $\times$ oil source)) interactions.

\section{Discussion}

The oil sources used in this experiment were chosen because they have different physical properties. Fish oil has higher levels of saturated fatty acids and higher $n-3$ polyunsaturated fatty (PUFA) acids than olive oil while

Table 5

Astaxanthin retention in the muscle of rainbow trout fed the different diets ${ }^{(1)(2)(3)}$

\begin{tabular}{|c|c|c|c|c|c|}
\hline \multirow[t]{2}{*}{ Parameter } & \multirow[t]{2}{*}{ Periods } & \multicolumn{4}{|l|}{ Treatments } \\
\hline & & ASTFI & ASTOL & ALGFI & ALGOL \\
\hline \multirow[t]{3}{*}{ Astaxanthin retention } & $0-2 \mathrm{w}$ & $4.42 \pm 3.36^{\mathrm{b}}$ & $8.36 \pm 2.80^{\mathrm{a}}$ & n.a. ${ }^{(4)}$ & n.a. \\
\hline & $0-4 \mathrm{w}$ & $2.43 \pm 2.12^{\mathrm{a}, \mathrm{b}}$ & $5.65 \pm 3.85^{\mathrm{a}}$ & $1.26 \pm 0.31^{\mathrm{b}}$ & $1.87 \pm 0.81^{\mathrm{a}, \mathrm{b}}$ \\
\hline & $0-6 \mathrm{w}$ & $5.97 \pm 2.03^{\mathrm{a}}$ & $5.28 \pm 1.43^{\mathrm{a}}$ & $1.80 \pm 1.09^{\mathrm{b}}$ & $2.79 \pm 0.78^{\mathrm{b}}$ \\
\hline
\end{tabular}

\footnotetext{
${ }^{(1)}$ Data are mean $\pm \mathrm{SD}, n=4$.

${ }^{(2)}$ Means on the same line not sharing the same letter are significantly different $(P<0.05)$.

${ }^{(3)}$ AST, ALG: diets containing synthetic astaxanthin or algae, respectively; FI, OL: diets containing fish oil or olive oil, respectively.

${ }^{(4)}$ n.a.: not available.
} 
olive oil (extra virgin quality and cold extracted) had higher levels of monounsaturated fatty acids than fish oil. The fish oil used was not attributed to one particular fish species but to Scandinavian fish as specified by the manufacturer. Fatty acid contents were in the range of fatty acid contents reported for other fish oils (Hardy et al., 1987; Christiansen et al., 1993; Bjerkeng et al., 1999) with a PUFA content similar to herring oil PUFA content (medium PUFA).

The strain of H. pluvialis used in this experiment has been reported in previous studies to contain astaxanthin as the major carotenoid pigment in an amount as high as $98.6 \%$ of total carotenoids and to be efficient in terms of trout flesh pigmentation (Barbosa et al., 1999; MendesPinto et al., 2004). As algae occur in an encysted form surrounded by a thick cell wall which may prevent astaxanthin absorption by fish (Choubert and Henrich, 1993), algae biomass was carefully ground before being added to the diets. However, this grinding step may explain some differences observed in astaxanthin concentrations between different series of test diets.

The addition of vegetable oil as olive oil up to $10 \%$ in the diet of rainbow trout did not affect growth or derived parameters such as specific growth rates or feed conversion ratio. This is in agreement with previous reports for salmon receiving in their diet vegetable oils such as soybean oil (Hardy et al., 1987; Thomassen and Røsjø, 1989; Regost et al., 2004), rapeseed oil (Thomassen and Røsjø, 1989; Regost et al., 2004; Torstensen et al., 2004) or olive oil (Torstensen et al., 2004), or for European sea bass receiving in their diet rapeseed or olive oil (Mourente et al., 2005).

As there was a difference in amounts of astaxanthin in the test diets, serum astaxanthin concentrations of trout fed different diets were calculated as ratio [total blood astaxanthin per unit body weight to cumulative astaxanthin intake per unit body weight]. In this case our results showed that fish fed diets containing synthetic astaxanthin displayed higher serum concentration than those fed astaxanthin from this strain of algae. This is in agreement with our earlier work (Mendes-Pinto et al., 2004).

Our result also showed that fish fed diets containing olive oil displayed higher serum astaxanthin levels than those fed diets containing fish oil. Decreasing carotenoid absorption when dispersed in PUFA was reported in rat (Clark et al., 2000). Moreover, in the rat, dietary lipids of plant origin, in contrast to those of animal origin, promote the accumulation of $\beta$-carotene in plasma (Alam et al., 1989) by influencing chilomicron metabolism (Lambert et al., 1998). The reason for this is not fully understood. However, results in salmon seem contradictory as blood plasma astaxanthin was unaffected by high PUFA dietary oil (Bjerkeng et al., 1999). An explanatory for this discrepancy would be that oils contain different amounts of stanol and sterols which interfere with the absorption of carotenoids (Nguyen, 1999).

In our experiment fish muscle colour parameters reacted differently according to fish feed. Hue $\left(H\left(^{\circ}\right)_{a b}\right)$ was not affected by diets. Lightness $\left(L^{*}\right)$ decreased while chroma $\left(C^{*}\right), a^{*}$ and $b^{*}$ increased over time as fish consumed pigmented diets. This is in agreement with previous findings (Choubert, 1982). Muscle colour attributes were more affected by astaxanthin source than by oil source. Fish fed naturally identical synthetic astaxanthin showed higher chroma, $a^{*}$ and $b^{*}$ than fish fed algae. The lower efficacy of algae $H$. pluvialis was reported previously for rainbow trout (Sommer et al., 1991; Choubert and Henrich, 1993; Choubert et al., 1995) and was explained as probably due at least in part to the high amount of esterified carotenoid (Renstrøm et al., 1981) which has been found to be less efficiently used by salmonids (Storebakken et al., 1987).

Reports of dietary oil source effects on colour parameters of fish muscle have been contradictory and are not yet understood. Variations in colour parameters of fish muscle fed vegetable oils are also confusing; no variation in $a^{*}$ for salmon fed soybean oil was reported (Thomassen and Røsjø, 1989) while a decrease in $a^{*}$ was noted in salmon muscle fed rapeseed oil (Thomassen and Røsjø, 1989; Regost et al., 2004) or soybean oil (Regost et al., 2004), fish muscle being less red than that of fish fed fish oil diets.

Muscle astaxanthin retention was higher for fish fed synthetic astaxanthin than for fish fed algae. Although astaxanthin retention data are sparse in the literature retention coefficients noted in our experiment were of the same order than those reported earlier (Choubert and Henrich, 1993; Choubert et al., 1995) for other algae strains. According to Choubert et al. (1995) this low retention is likely due to the low digestibility of algae astaxanthin.

Fish receiving the diet with synthetic astaxanthin plus olive oil showed a higher muscle astaxanthin retention than fish fed the diet with synthetic astaxanthin plus fish oil. The only main reason which may be put forward is the difference in fatty acid composition which may affect i) astaxanthin absorption across the gastrointestinal tract of fish, or ii) molecular processes involved in chylomicron turn-over as noted for $\beta$ carotene in women fed a meal rich in sunflower oil ( $\mathrm{Hu}$ et al., 2000). However, in salmon fed diets with capelin or high PUFA oil, similar muscle astaxanthin retentions were observed (Bjerkeng et al., 1999) which are not yet explained. 


\section{Conclusion}

One interesting observation in this study was that olive oil can be used up to $10 \%$ replacement of dietary fish oil for rainbow trout during the grow out period (6 weeks) without negative effects on mortality or growth. For astaxanthin content in serum and muscle of trout the effects of dietary oil source gave faint results. On one hand, fish fed diets OL displayed higher $(P<0.05)$ serum astaxanthin levels than those fed diets FI. On the other hand after 6 weeks of experiment muscle astaxanthin levels were not different $(P>0.05)$ for fish fed olive or fish oil. The similar retention of astaxanthin in trout fed diets with FI and OL oils cannot be explained at present and further investigations are necessary. Moreover organoleptic study should be made to find changes, if any, in quality parameters of fish muscle.

\section{Acknowledgements}

We acknowledge with thanks Laurence Larroquet and Karine Chapot for their technical assistance and the technical staff of the INRA experimental fish farm of Donzacq (Landes Department) for supplying the experimental animals. The authors would like to thank also DSM Nutritional Products France (formerly Produits Roche France) Paris La Défense, France for providing CAROPHYLL ${ }^{\circledR}$ pink. M.M. Mendes-Pinto's stay in France was made possible through the Portugal-France Scientific and Technical Cooperation Exchange Programme (ICCTI-French Embassy at Lisbon, Portugal, project 2000/417-P8).

\section{References}

Alam, B.S., Alam, S.Q., Bendich, A., Shapiro, S.S., 1989. Effects of dietary lipids on hepatic and plasma beta-carotene and vitamin A levels in rats fed beta-carotene. Nutr. Cancer 12, 57-60.

Barbosa, M.J., Morais, R., Choubert, G., 1999. Effects of carotenoid source and dietary lipid content on blood astaxanthin concentration in rainbow trout (Oncorhynchus mykiss). Aquaculture 176, $331-341$.

Bell, J.G., McEvoy, J., Tocher, D.R., McGhee, F., Campbel, P.J., Sargent, J.R., 2001. Replacement of fish oil with rapeseed oil in diets of Atlantic salmon (Salmo salar) affects tissue lipid compositions and hepatocyte fatty acid metabolism. J. Nutr. 131, 1535-1543.

Bell, J.G., Henderson, R.J., Tocher, D.R., McGhee, F., Dick, J.R., Porter, A., Smullen, R.P., Sargent, J.R., 2002. Substituting fish oil with palm oil in the diet of Atlantic salmon (Salmo salar) affects muscle fatty acid compositions and hepatic fatty acid metabolism. J. Nutr. 132, 222-230.

Bjerkeng, B., Hatlen, B., Wathne, E., 1999. Deposition of astaxanthin in fillets of Atlantic salmon (Salmo salar) fed diets with herring, capelin, sandeel, or Peruvian high PUFA oils. Aquaculture 180, 307-319.
Choubert, G., 1982. Method for colour assessment of canthaxanthin pigmented rainbow trout (Salmo gairdneri, Rich.). Sci. Aliment. 2, 451-463.

Choubert, G., Henrich, O., 1993. Carotenoid pigmentation of the green alga Haematococcus pluvialis: assay on rainbow trout, Oncorhynchus mykiss, pigmentation in comparison with synthetic astaxanthin and canthaxanthin. Aquaculture 112, 217-226.

Choubert, G., Luquet, P., 1982. Fixation et retention musculaire de la canthaxanthine par la truite arc-en-ciel. Ann. Zootech. 31, 1-10.

Choubert, G., Storebakken, T., 1989. Dose response to astaxanthin and canthaxanthin pigmentation of rainbow trout fed various dietary carotenoid concentration. Aquaculture 81, 69-77.

Choubert, G., Milicua, G., Gómez, R., Sancé, S., Petit, H., NégresSadargues, G., Castillo, R., Trilles, J.P., 1995. Utilization of carotenoids from various sources by rainbow trout: muscle colour, carotenoid digestibility and retention. Aquac. Int. 3, 1-12.

Choubert, G., Blanc, J.-M., Vallée, F., 1997. Colour measurement, using CIE-LCH colour space, of muscle of rainbow trout, Oncorhynchus mykiss (Walbaum), fed astaxanthin: effects of family, ploidy, sex, and location of reading. Aquac. Res. 28, 15-22.

Christiansen, R., Waagbø, R., Torrissen, O.J., 1993. Effects of polyunsaturated fatty acids and vitamin $\mathrm{E}$ on flesh pigmentation in Atlantic salmon (Salmo salar). In: Kaushik, S.J., Luquet, P. (Eds.), Fish Nutrition in Practice. INRA Éditions, Versailles, pp. 339-343.

CIE, Commission Internationale de l'Éclairage, 1976. Colorimetry, Publication no 15. Bureau central de la CIE, Vienna, Austria. 14 pp.

Clark, R.M., Yao, L., She, L., Furr, H.C., 2000. A comparison of lycopene and astaxanthin absorption from corn oil and olive oil emulsions. Lipids 35, 803-806.

Folch, J., Lees, M., Sloane-Stanley, G.H., 1957. A simple method for the isolation and purification of total lipids from animal tissues. J. Biol. Chem. 226, 497-509.

Hardy, R.W., Scott, T.M., Harrell, L.W., 1987. Replacement of herring oil with menhaden oil, soybean oil, or tallow in the diets of Atlantic salmon raised in marine net-pens. Aquaculture 65, 267-277.

Hu, X., Jandacek, R.J., White, W.S., 2000. Intestinal absorption of $\beta$-carotene ingested with a meal rich in sunflower oil or beef tallow: postprandial appearance in triacylglycerol-rich lipoproteins in women. Am. J. Clin. Nutr. 71, 1170-1180.

Lambert, M.S., Avella, M.A., Botham, K.M., Mayes, P.A., 1998. Comparison of short- and long-term effects of different dietary fats on the hepatic uptake and metabolism of chylomicron remnants in rats. Br. J. Nutr. 79, 203-211.

Lorenz, R.T., Cysewski, T., 2000. Commercial potential for Haematococcus microalgae as a natural source of astaxanthin. Tibtechnology $18,160-166$.

Mendes-Pinto, M.M., Raposo, M.F., Bowen, J., Young, A.J., Morais, R., 2001. Evaluation of different cell disruption processes on encysted cells of Haematococcus pluvialis: effects on astaxanthin recovery and implications for bio-availability. J. Appl. Phycol. 13, 19-24.

Mendes-Pinto, M.M., Choubert, G., Morais, R., 2004. Effect of dietary bile extracts on serum response of astaxanthin in rainbow trout (Oncorhynchus mykiss): a preliminary study. Aquac. Nutr. 10, 353-357.

Mourente, G., Good, J.E., Bell, J.G., 2005. Partial substitution of fish oil with rapeseed, linseed and olive oils in diets for European sea bass (Dicentrarchus labrax L.): effects on flesh fatty acid composition, plasma prostaglandins $\mathrm{E}_{2}$ and $\mathrm{F}_{2 \alpha}$, immune function and effectiveness of a fish oil finishing diet. Aquac. Nutr. 11, 25-40.

Nguyen, T.T., 1999. The cholesterol-lowering action of plant stanol esters. J. Nutr. 129, 2109-2112. 
Nikinmaa, M., Soivo, A., Railo, E., 1981. Blood volume of Salmo gairdneri: influence of ambient temperature. Comp. Biochem. Physiol. 69A, 767-769.

Regost, C., Jakobsen, J.V., Rørå, AM., 2004. Flesh quality of raw and smoked fillets of Atlantic salmon as influenced by dietary oil sources and frozen storage. Food Res. Int. 37, 259-271.

Renstrøm, B., Borch, G., Skulberg, O.M., Liaaen-Jensen, S., 1981. Optical purity of $\left(3 \mathrm{~S}, 3^{\prime} \mathrm{S}\right)$-astaxanthin from Haematococcus pluvialis. Phytochemisty 20, 2561-2564.

Santha, N.C., Ackman, R.G., 1990. Nervonic acid versus tricosanoic acid as internal standards in quantitative gas chromatographic analyses of fish oil longer-chain $n-3$ polyunsaturated fatty acid methyl esters. J. Chromatogr. Biomed. Appl. 533, 1-10.

SAS, 1989. SAS/STAT ${ }^{\circledR}$ User's Guide. Version 6, Fourth edition. SAS Institute Inc., Cary, NC, USA. 1028 pp.

Schüep, W., Schierle, J., 1995. Determination of stabilized, added astaxanthin in fish feeds and pre-mixes. In: Britton, G., LiaaenJensen, S., Pfander, P. (Eds.), Carotenoids. Isolation and Analysis, vol. 1A. Birkhäuser Verlag, Basel, Switzerland, pp. 273-276.
Sommer, T.R., Potts, W.T., Morrisy, N.M., 1991. Utilization of microalgal astaxanthin by rainbow trout (Oncorhynchus mykiss). Aquaculture 94, 79-88.

Storebakken, T., Foss, P., Austreng, E., Liaasen-Jensen, S., Manz, U., 1987. Carotenoids in diets for salmonids: IV. Pigmentation of Atlantic salmon with astaxanthin, astaxanthin-dipalmitate and canthaxanthin. Aquaculture 65, 279-292.

Thomassen, M.S., Røsjø, C., 1989. Different fats in feed for salmon: influence on sensory parameters, growth rate and fatty acids in muscle and heart. Aquaculture 79, 129-135.

Torrissen, O.J., Hardy, R.W., Shearer, K.D., 1989. Pigmentation of salmonids - carotenoid deposition and metabolism. Rev. Aquat. Sci. 1, 209-225.

Torstensen, B.E., Frøyland, L., Lie, Ø., 2004. Replacing dietary fish oil with increasing levels of rapeseed oil and olive oil - effects on Atlantic salmon (Salmo salar L.) tissue and lipoprotein lipid composition and lipogenic enzyme activities. Aquac. Nutr. 10, 175-192.

Wyszecki, G., Stiles, W.S., 1967. Color Science. John Wiley and Sons, New York, USA. 628 pp. 